\title{
Upaya Meningkatkan Kreativitas Anak Usia 5 - 6 Tahun Melalui Permainan Eksplorasi di PAUD Mulia Kecamatan Percut Sei Tuan Kabupaten Deli Serdang
}

Received : 10 Maret 2020

Revised : 20 April 2020

Accepted : 2 Juni 2020

\author{
Iis Damayanati Pratiwi ${ }^{1}$, Nasriah ${ }^{2}$ \\ Fakultas Ilmu Pendidikan \\ Universitas Negeri Medan \\ Jln. Willem Iskandar Psr V Medan Estate \\ E-mail : $\underline{\text { iisdamayanti@gmail.com }}$
}

\begin{abstract}
Abstrak. Permasalahan pada penelitian ini adalah: (1) Rendahnya kreativitas pada anak (2) anak masih kurang percaya diri dalam mengerjakan tugas, (3) anak merasa bosan, ngantuk pada saat mengerjankan tugas, (4) kurangnya penggunaan permainan eksplorasi dalam pembelajaran khususnya untuk meningkatkan kreativitas anak, (5) Sistem pendidikan yang lebih memfokuskan pada kemampuan akademik seperti membaca, menulis dan berhitung (calistung). Penelitian ini bertujuan untuk mengetahui perkembangan kreativitas anak usia 5-6 tahun dengan menggunakan permainan eksplorasi "bermain pasir" di PAUD Mulia Kec. Percut Sei Tuan Kab. Deli Serdang.

Hasil observasi dan refleksi pada siklus I pertemuan 1 diperoleh nilai rata-rata $10,05 \%$, anak yang tergolong dalam kemampuan kreativitas sangat baik $0(0 \%)$, anak yang tergolong baik $0(0 \%)$, anak yang tergolong cukup $15(75 \%)$, dan anak yang kurang $5(25,8 \%)$. Hasil pengamatan siklus II pertemuan II diperoleh nilai rata-rata $12,75 \%$, anak yang tergolong sangat baik $0(0 \%)$, anak yang tergolong baik $3(15 \%)$, anak yang tergolong cukup 17 (85\%), anak yang tergolong kurang $0(0 \%)$. Pada siklus II pertemuan 1 diperoleh nilai rata-rata anak 16,95\%, anak yang tergolong sangat baik 7 (35\%), anak yang tergolong baik $8(40 \%)$, anak yang tergolong cukup $5(25 \%$,), dan anak yang tergolong kurang $0(0 \%)$. Hasil pengamatan siklus II pertemuan II diperoleh nilai rata-rata anak 19,95\%, anak yang tergolong sangat baik 11(55\%), anak yang tergolong baik 7 (35\%), anak yang tergolong cukup 2 (10\%), dan anak YANG tergolong kurang $0(0 \%)$.

Dan tidak ditemukan lagi anak yang tergolong kurang kreatif. Berdasarkan hasil penelitian tersebut, dapat disimpulkan bahwa kegiatan permainan eksplorasi "bermain pasir" dapat meningkatkan kemampuan kreativitas anak. Oleh karena itu, kegiatan permainan eksplorasi "bermain pasir" dapat dijadikan salah satu alternatif dalam meningkatkan kreativitas anak usia 5-6 tahun di PAUD Mulia Kec. Percut Sei Tuan Kab. Deli Serdang.
\end{abstract}

Kata Kunci: Kreativitas, Permainan Eksplorasi

\section{PENDAHULUAN}

Perkembangan kreativitas anak sangat penting dikembangkan sejak usia dini, agar anak memiliki keterampilan dan daya cipta agar anak dapat menyesuaikan diri dilingkungan sekitarnya. Seharusnya tahap perkembangan kreativitas anak usia 5-6 tahun, menurut supriadi (dalam Rachmawati dan Kurniati (2005:17), mampu menunjukkan sikap kreativitas diantaranya adalah rasa ingin tahu yang besar, bersifat imajinatif, tekun dan tidah mudah bosan, berani mengambil resiko, kaya akan inisiatif, kritis terhadap pendapat orang lain. 
Berdasarkan pengamatan yang penulis lakukan selama menjadi guru di PAUD MULIA, ternyata perkembangan kreativitas anak usia dini saat ini masih rendah, hal ini ditandai dengan munculnya 10 dari 20 orang anak yang kurang menunjukkan sikaf kreativitas, seperti anak tidak mau mencoba menambah bentuk lain dari contoh yang sudah ada, anak masih kurang percaya diri dalam melakukan suatu kegiatan, dan selain itu anak juga banyak yang terlihat bosan, ngantuk, kurang tertarik, dan bahkan ada yang main sendiri saat mengerjakan keterampilan seperti menggambar dan mewarnai. Dan kurangnya penggunaan permainan eksplorasi di sekolah. Hal ini disebabkan karena faktor orang tua yang mengharuskan anaknya bisa membaca, menulis, dan berhitung, kurangnya pemahaman pendidik dalam metode apa yang dapat mengembangkan kreativitas anak, media yang digunakan juga hanya sekedar buku lembar kerja, seperti kegiatan menggambar dan mewarnai saja untuk meningkatkan kreativitas anak.

Guru dalam pelaksanaan kegiatan pembelajaran adalah dengan memberikan kesempatan pada anak untuk melakukan berbagai kegiatan dengan mengeksplorasi lingkungannya dan melakukan interaksi yang aktif dengan orang dewasa dan lingkungannya. Guru harus menciptakan situasi yang mengandung makna penting, yang memungkinkan berkembangnya kekuatan yang dimiliki anak dan perluasan minat anak serta pengembangan kreativitas dan tanggung jawab, baik secara perseorangan maupun secara kelompok.

Berbagai cara yang dapat dilakukan guru agar kereativitas anak berkembang dengan baik, Salah satu diantaranya ialah dengan permainan eksplorasi yang dibentuk dalam permainan pasir yaitu seperti, membangun istana pasir, membangun gunung pasir, membuat patung, membuat cap tangan dan kaki, mengamati tekstur pasir dengan kaca pembesar, sehingga membuat anak menjadi tertarik, memunculkan rasa ingin tahu dan mengembangkan imajinasinya. Dengan adanya permaianan eksplorasi yaitu bermain pasir dapat dilihat sejauh mana perkembanga kreativitas anak berkembang sesuai dengan harapan, khususnya senang mencoba sesuatu yang baru yaitu melakukan suatu kegiatan yang belum pernah dilakukan, tekun dan tidak mudah bosan yaitu senang melakukan kegiatan, berani mengambil resiko yaitu mau melakukan kegiatan yang di perintahkan, mau bertanya, bersifat imajinatif dapat menceritakan hasil karyanya kepada orang lain, kaya inisiatif yaitu dapat menghargai pendapat orang lain.

Mengingat pentingnya meningkatkan kreativitas anak untuk mengoptimalkan potensi yang dia miliki, maka hal ini yang mendorong penulis melakukan penelitian tentang "Upaya Meningkatkan Kreativitas Anak Usia 5-6 Tahun Melalui Permainan Eksplorasi Di PAUD Mulia Kec. Percut Sei Tuan Kab. Deli serdang Tahun Ajaran 2015/2016"

\section{METODOLOGI PENELITIAN}

Jenis penelitian yang dilaksanakan oleh peneliti adalah merupakan penelitian tindakan kelas (PTK), yang bertujuan untuk mengembangkan kreativitas anak melalui permainan eksplorasi

Subjek dalam penelitian tindakan kelas ini adalah anak usia 5-6 tahun di PAUD MULIA berjumlah 20 orang, yang terdiri dari 9 anak laki-laki dan 11 anak perempuan. Sedangkan objek penelitian ini adalah mengembangkan kreativitas anak usia 5-6 tahun melalui Permainan Eksplorasi di PAUD MULIA Kec. Percut Sei Tuan Kab. Deli Serdang 
Dalam penelitian ini teknik pengumpulan data yang digunakan adalah observasi. Metode Penelitian ini menggunakan desain model Kemmis dan Mc. Taggart (Dewi, 2010:122).Rencana penelitian akan dilakukan dengan 2 siklus, yakni siklus I dan siklus II. Setiap siklus terdiri dari empat tahap, yaitu tahap: (1) Perencanaan (planning),(2) Tindakan (acting),(3) Pengamatan (observing) dan (4) Refleksi (reflect). Hasil refleksi siklus I digunakan sebagai acuan dalam menentukan perbaikan pada siklus II. Sedangkan hasil refleksi siklus II akan digunakan sebagai acuan untuk rencana perbaikan pembelajaran selanjutnya.

Tabel 1. Kisi-kisi perkembangan kreativitas Anak

\begin{tabular}{|c|c|c|c|}
\hline No & Variabel & Indikator & Deskriptor \\
\hline 1 & & $\begin{array}{l}\text { Rasa ingin tahu } \\
\text { yang besar }\end{array}$ & $\begin{array}{l}\text { a. Rajin bertanya dan memberi tanggapan } \\
\text { pada saat bermain pasir } \\
\text { b. Bertanggung jawab pada saat bermain } \\
\text { pasir } \\
\text { c. Mengamati benda yang ada disekeliling } \\
\text { pada saat bermain pasir } \\
\text { d. Minat belajar yang besar }\end{array}$ \\
\hline 2 & & $\begin{array}{l}\text { Bersifat } \\
\text { imajinatif }\end{array}$ & $\begin{array}{l}\text { a. Mengeluarkan gagasan baru pada saat } \\
\text { bermain pasir } \\
\text { b. Menceritakan hasil karya yang telah } \\
\text { dibuat pada saat bermain pasir } \\
\text { c. Melakukan tindakan pada saat bermain } \\
\text { pasir } \\
\text { d. Ikut melaksanakan kegiatan }\end{array}$ \\
\hline 3 & & $\begin{array}{l}\text { Tekun dan tidak } \\
\text { mudah bosan } \\
\text { belajar }\end{array}$ & $\begin{array}{l}\text { a. Konsentrasi (mampu memusatkan } \\
\text { perhatian) pada saat bermain pasir } \\
\text { b. Belajar mandiri pada saat bermain pasir } \\
\text { c. Senang belajar pada saat bermain pasir } \\
\text { d. Melaksanakn tugas secara cepat dan } \\
\text { tuntas }\end{array}$ \\
\hline 4 & & $\begin{array}{l}\text { Berani } \\
\text { mengambil resiko }\end{array}$ & $\begin{array}{l}\text { a. Berani mengakui kesalahan yang dibuat } \\
\text { pada saat bermain pasir } \\
\text { b. Berani menerima tugas pada saat bermain } \\
\text { pasir } \\
\text { c. Tidak takut berbeda pendapat dengan yang } \\
\text { lain pada saat bermain pasir } \\
\text { d. Siap menghadapi tantangan }\end{array}$ \\
\hline 5 & & Kaya inisiatif & $\begin{array}{l}\text { a. Suka memberikan pendapat dan saran } \\
\text { pada saat bermain pasir } \\
\text { b. Mudah diajak diskusi pada saat bermain } \\
\text { pasir } \\
\text { c. Menghargai pendapat orang lain pada saat } \\
\text { bermain pasir } \\
\text { d. Menyelesaikan tugas secara kreatif }\end{array}$ \\
\hline 6 & & $\begin{array}{l}\text { Keritis terhadap } \\
\text { pendapat orang } \\
\text { lain }\end{array}$ & $\begin{array}{l}\text { a. Menghargai pendapat orang lain } \\
\text { b. Mempertahankan pendapat/gagasan } \\
\text { sendiri } \\
\text { c. Brtanggung jawab } \\
\text { d. Percaya diri }\end{array}$ \\
\hline
\end{tabular}




\section{HASIL DAN DISKUSI}

Untuk memperoleh data dalam peneliti ini, peneliti menggunakan teknik observasi. Dari hasil observasi terhadap 20 orang anak dikelompok B PAUD Mulia, maka peneliti akan mendeskripsikan data-data temuan penelitian yang telah dilakukan selama siklus I dan siklus II. Dimana pada setiap siklus dilakukan 2 kali pertemuan.

Dari observasi, dapat dilihat bahwa dengan kegiatan membatik memberikan perbedaan pada perkembangan kreativitas anak pada siklus I dan Siklus II. Perbedaan tersebut dapat dilihat dalam diagram dibawah ini

Berdasarkan hasil pengamatan pada siklus II selama 2 kali pertemuan, peneliti melihat bahwa kreativitas anak sudah meningkat dan tergolong Sangat baik. Tabel 4.4 diatas menunjukkan bahwa hingga pertemuan kedua pada siklus II perkembangan kreativitas anak sebagai berikut, sebanyak 11 orang ( $55 \%$ ) tergolong sangat baik, dan 7 orang (35 $\%)$ tergolong baik, dan sebanyak 2 orang ( $10 \%$ ) tergolong cukup. Dapat dilihat diagram batang dibawah ini. 


\section{Rangkuman Diagram Batang kreativitas Anak pada Siklus I dan II Pertemuan 1 dan 2}

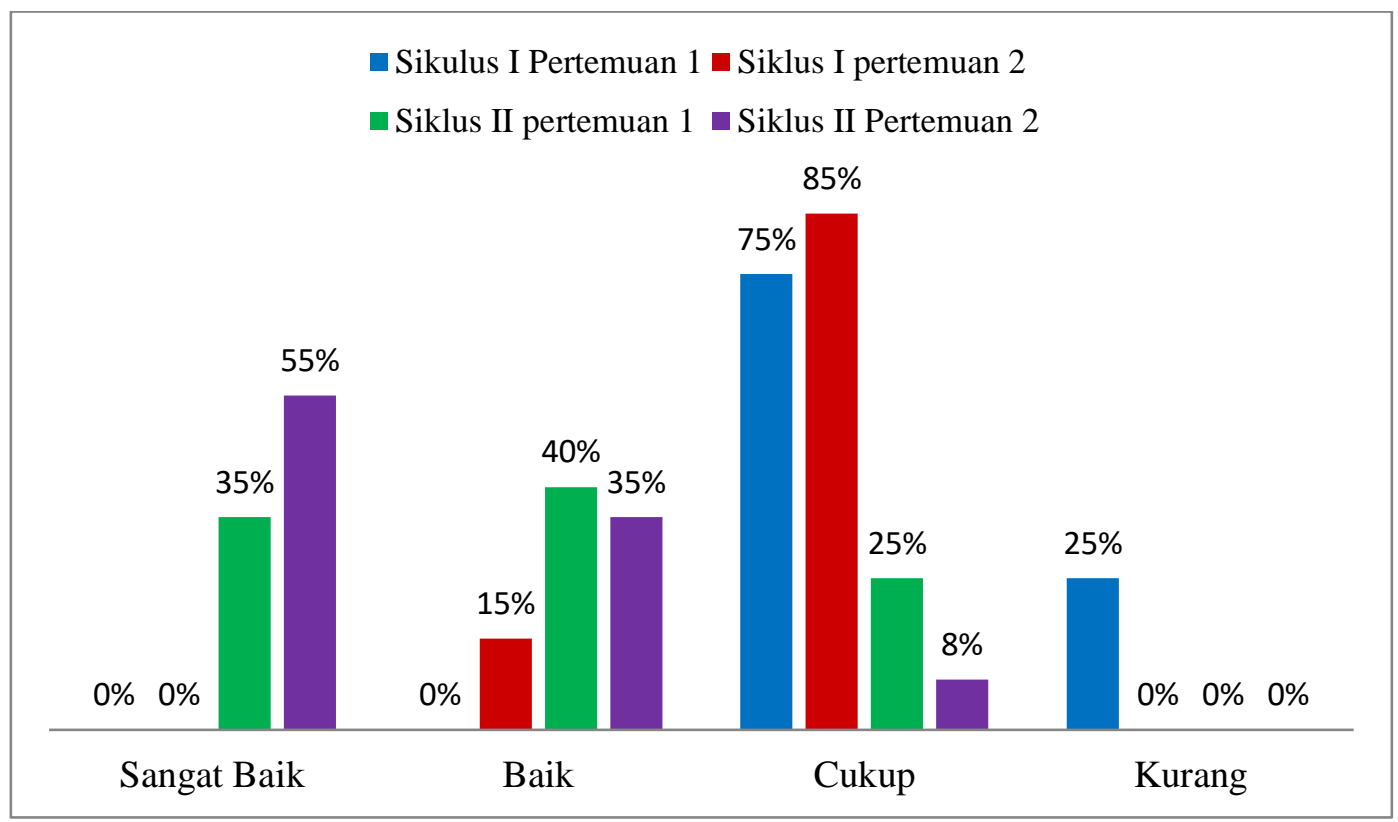

\section{PEMBAHASAN}

Dengan melihat perkembangan kreativitas anak yang meningkat secara signifikan dari siklus I $(2,75 \%)$ dan siklus II (3\%). Berbagai upaya yang dapat dilakukan guru untuk meningkatkan kreativita anak usia 5-6 tahun di PAUD Mulia melalui permainan eksplorasi yaitu bermain pasir dalam kegiatan berlangsung anak dapat memiliki rasa ingin tahu yang besar, bersifat imajinatif, tekun dan tidak muda bosan belajar, berani mengambil resiko, kaya inisiatif, Keritis terhadap pendapat orang lain dengan cara menyenangkan. Melalui bermain pasir yang diberikan kepada anak ternyata cukup efektif dan dapat menarik perhatian anak untuk menciptakan sesuatu sesuai dengan keinginannya. Temuan ini sejalan dengan pendapat yang dikemukakan oleh Supriadi (2001:7) kreativitas adalah kemampuan seseorang untuk melahirkan sesuatu yang baru, baik berupa gagasan maupun karya nyata, yang relatif berbeda dengan yang telah ada sebelumnya.

Sesuai dengan hasil penelitian dan peningkatan yang signifikan pada perkembangan kreativitas anak usia 5-6 tahun di PAUD Mulia dapat terlihat dari hasil tindakan pada siklus II ada peningkatan perkembangan kreativitas anak melalui permainan eksplorasi. Dengan demikian maka hipotesis tindakan dalam penelitian ini dapat terjawab bahwa dengan adanya kegiatan bermain pasir dapat meningkatkan kreativitas anak usia 5-6 tahun di PAUD Mulia Kec. Percut Sei Tuan Kab. Deli Serdang T.A 2015/2016. 


\section{SIMPULAN}

Berdasarkan hasil penelitian dan pengolahan data pada sub bab sebelumnya dapat di ambil kesimpulan, yaitu :

1. Peningkatan kreativitas anak pada siklus I pertemuan 1 yang tergolong dalam kemampuan kreativitas sangat baik $0(0 \%)$, anak yang tergolong baik $0(0 \%)$, anak yang tergolong cukup $15(75 \%)$, dan anak yang kurang 5(25\%). Hasil pengamatan pertemuan II, anak yang tergolong sangat baik $0(0 \%)$ anak, yang tergolong baik 3 (15\%), yang tergolong cukup 17( $85 \%$ ) anak yang kemampuan kreativitas kurang 0 $(0 \%)$.

2. Pada siklus II pertemuan 1 diperoleh nilai rata-rata anak $16,95 \%$, anak yang tergolong sangat baik 7 (35\%), anak yang tergolong baik 8 (40\%), $5(25 \%)$ orang anak yang kemampuan kreativitasnya cukup, dan 0 orang anak kemampuan kreativitasnya kurang. Hasil pengamatan pertemuan II diperoleh nilai rata-rata anak $19,95 \%$, anak yang tergolong sangat baik $11(55 \%)$, anak yang tergolong baik 7 (35\%), anak yang tergolong cukup $2(10 \%)$, dan 0 orang anak kemampuan kreativitasnya kurang.

3. Melalui permainan eksplorasi yaitu kegiatan bermain pasir dapat meningkatkan kreativitas anak usia 5-6 tahun di PAUD Mulia Kec. Percut Sei Tuan Kab. Deli Serdang Tahun Ajaran 2015/2016.

Berdasarkan kesimpulan diatas, maka peneliti mengajukan beberapa saran yaitu :

1. Bagi guru diharapkan dapat menggunakan kegiatan bermain pasir untuk mengembangkan kreativitas pada anak .

2. Bagi pihak sekolah diharapkan untuk lebih memberikan perhatian terhadap pengembangan kreativitas anak dengan mengikut sertakan guru-guru mengikuti pelatihan-pelatihan, melalui penyedian sumber belajar, alat, bahan dan media yang mampu mengembangkan kreativitas anak.

3. Bagi peneliti diharapkan untuk dapat menerapkan kegiatan bermain pasir dalam kegiatan pembelajaran di tamak kanak-kanak saat terjun didunia kerja.

4. Bagi peneliti selanjutnya diharapkan untuk dapat melanjutkan penelitian ini, sehingga diharapkan agar dapat melakukan penelitian yang lebih baik agar diperoleh data yang signifikan.

\section{DAFTAR RUJUKAN}

Aqib, Zainal..209. Penelitian Tindakan Kelas. Bandung : YramaWidya

Dewi, Rosmala. 2010. Profesionalisasi Guru Melakukan Penelitian Tindakan Kelas. Medan : Pasca Sarjana Unimed

Purwanto, Edi. (Desember 2012) Program Studi Bimbingan dan Konseling. Jurnal "PSIKOPEDAGOGIA" 2012, Vol 1, No 2, ISSN : 2301-6160

Marjohan.2011. Anak Cerdas (online), dalam http://www.lp2i.org/anak-cerdas- 6121.info diakses 15 September 2015)

Munandar, Utami. 2012. Pengembangan Kreativitas Anak Berbakat. Jakarta: Rineka Cipta.

Musbikin, Iman. 2012. Pintar Mengatasi Masalah Tumbuh Kembang anak. Jakarta: Flash Books.

Mutiah, Diana. 2010. Psikologi Bermain Anak Usia Dini. Jakarta: Kencana Prenada Media Group.

Nurjatmika, Yusep. 2012. Ragam Aktivitas Harian untuk TK. Jogjakarta: Diva Press. 
Purwanto, Edi. (Desember 2012) Program Studi Bimbingan dan Konseling. Jurnal "PSIKOPEDAGOGIA" 2012, Vol 1, No 2, ISSN : 2301-6160

Rachmawati, dan Kurniati. 2010. Strategi Pengembangan Kreativitas Pada Anak Usia TK. Jakarta: Kencana.

Riyadi, dan Sukarmin. 2009. Asuhan Keperawatan Pada Anak. Yogyakarta: Graha Ilmu.

Saleh, Samsudar. 2004. Statistik Deskriptif. Yogyakarta: UPP AMP YKPN.

Siswanto dan Lestari. 2012. Pembelajaran Aktif dan 100 Permainan Kreatif. Yogyakarta: Andi.

Sudjana.2005. Metode Statistika. Bandung: Tarsito

Sujiono.Y N. 2009. Konsep Dasar Pendidikan Anak Usia Dini. Jakarta: Indeks.

Suratno.2005. Pengembangan Kreativitas Anak Usia Dini. Jakarta: Departemen Pendidikan Nasional Direktorat Jendral Pendididkan Tinggi Direktorat Pendidikan Tenaga Kependidikan dan Ketenagaan Perguruan Tinggi.

Susanto, Ahmad. 2012. Perkembangan Anak Usia Dini. Jakarta: Kencana

Tedjasaputra, Maykes. 2005 Bermain, Mainan Dan Permainan Untuk Pendidikan Usia Dini. Jakarta: Grasindo.

Yamin, M. Dan Jamilah, S.S. 2010 Panduan Pendidikan Anak Usia Dini. Jakarta: Gaung Persada Press. 